\title{
Ponto-Caspian and Mediterranean basins under conditions of the last glacial epoch
}

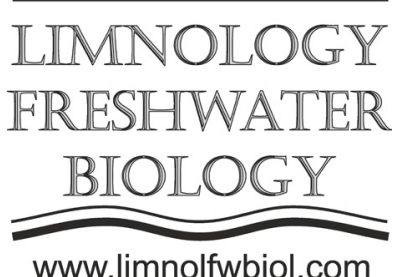

\author{
Yanina T.A. \\ Moscow State University, Leninskiye Gory Str., 1, Moscow, 119992, Russia
}

\begin{abstract}
The aim of this paper is comparison and correlation of events within the Ponto-Caspian basin system, as well as the events in individual parts of the Pontian-Mediterranean system, and the response of the systems to the global climatic changes during the last glacial epoch (MIS 2). The Pontian, Caspian and Mediterranean basins belonged to different types of the water basins, and evolved differently in the Late Pleistocene responding in different ways to the global climate changes. The study is based on the analysis and integration of the data published by numerous investigators of the region including the author and his numerous colleagues from many countries who have been working on the paleogeography of the Ponto-Caspian and Mediterranean regions in the Late Pleistocene.
\end{abstract}

Keywords: Caspian Sea, Azov-Black Sea basins, Marmara Sea, Eastern Mediterranean, MIS 2, sea level change, climate change, correlation

\section{Introduction}

Ponto-Caspian and Mediterranean basins present a system of intracontinental water bodies different in their natural characteristics and paleogeographic evolution. The Ponto-Caspian part of the system includes an isolated basin of the Caspian Sea, the AzovBlack Sea basin (periodically coming into a contact with the World Ocean), and the Manych Depression (occasionally functioning as a strait between the Caspian and the Pontian basins). The Mediterranean part of the system is composed of the eastern part of the basin noted for a permanent connection with the World Ocean; the Sea of Marmara (forming a kind of a "gate" between the Black and Mediterranean seas, periodically isolated from the adjacent sea basins), and Bosporus and Dardanelles straits. The evolution of the described natural system is influenced by a number of factors. The present paper is aimed at revealing connections between the global climate changes, as well as between sea level fluctuations on the Caspian, Black, and Azov seas and in the basins of the Eastern Mediterranean and the evolution of their environments.

The paleogeographic analysis is centered on the last glacial epoch (Late Valday or Ostashkov stage) wich is correlatable with MIS 2 (25-11.7 ka BP). The maximum cooling of the Valday glacial time is dated at 22 to $18 \mathrm{ka} \mathrm{BP}$. At that time the entire boreal region of Europe beyond the ice sheet represented a single hyperzone (Dynamics..., 2002) where the landscapes developed under a heavy influence of the cryogenesis. According to Rinterknecht et al. (2018), «local LGM» in the central part of the East European Plain is dated at 20 to $20.5 \mathrm{ka} \mathrm{BP}$, while the deglaciation began 17-15 ka BP. The Late Glacial (14.7-11.7 ka BP) was distinguished by short-term climatic fluctuations. The time interval included a pronounced warming with two distinct interstadials - Bølling (14.7-14.0 ka BP) and Allerød (13.6-12.9 ka BP), separated with a cooler interval between them known as Older Dryas. A considerable cooling - Younger Dryas - occurred 12.911.7 ka BP (Walker et al., 2009; NorthGRIP Project members 2004, etc.).

\section{Results and Discussion}

The paleogeographic analysis of the basins forming the system of the Pontian-CaspianMediterranean seas (subsequently referred to as the System) (Svitoch et al., 1998; Yanina, 2012; Krijgsman et al., 2019, etc.) permits to make a correlation between transgressive-regressive events in individual members of the System, to establish interrelations between them and to reconstruct the entire System functioning under conditions of global climate changes during MIS 2.

At the LGM all the basins in the System regressed. The LGM was marked by a deep regression of the World Ocean followed by a regression (Grimaldi one) of the Mediterranean Sea. In the isolated basins of the Marmara Sea, Pontian and Caspian seas the LGM was noted for cold and dry conditions, which resulted in a considerable drop of the water level (Grimaldi, New Euxinian and Elton regressions). The deglaciation epoch

*Corresponding author.

E-mail address: didacna@mail.ru (T.A. Yanina)

(C) Author(s) 2020. This work is distributed under the Creative Commons Attribution 4.0 License. 
led to rise of the water level in all the basins under consideration. The Mediterranean Sea, closely related with the World Ocean in its evolution, transgressed gradually, though irregularly. The "Great" Khvalynian transgression developed in the Caspian Sea because of the sharp increase of the water input into that lake. One of the reasons for the high level of the Khvalynian basin was a high threshold in the Manych depression. After it had been overcome, the Khvalynian water flowed into the New Euxinian (Pontian) lake basin. There were two stages distinguished in the Khvalynian water discharge corresponding to the transgression reaching the 45-50 $\mathrm{m}$ a.s.l. (initial phase of the warming) and 22-20 $\mathrm{m}$ a.s.1. (Bølling warming). The Pontian basin and the Marmara Sea levels depended heavily on the levels of the Caspian and Mediterranean seas. The Mediterranian did not exert any influence onto the New Euxinian basin of the Pont till the Holocene. It was twice subjected, however, to the Caspian impact due to the Manych Strait opening, which resulted in the rise of the New Euxinian basin level. Because of the low threshold in the Bosporus, the New Euxinian basin turned to a through-flow (drained) lake: it received the water flowing from the Khvalynian basin of the Caspian, and when the sea lake rose above the Borporus threshold the water flowed from the New Euxnian basin into the lake located in the Marmara Sea basin. Supposedly, the water could flow further, through the Dardanelles Strait into the eastern part of the Mediterranean (Grimaldi) Sea. So a system of flowthrough lakes developed as follows: Khvalynian basin of the Caspian Sea - New Euxinian (Pontian) basin Grimaldi basin of Mediterranean.

Under conditions of the ongoing deglaciation, when the transgressing Mediterranean Sea reached the Dardanelles Strait threshold, the strait opened and marine water entered the Sea of Marmara, the latter being gradually transformed into a marine basin. Another episode of the New Euxinian water outflow into the Marmara Sea occurred at the end of the Late Pleistocene, in the Younger Dryas. At the Holocene beginning, the marine regime acquired stability. The sea level reached the Bosporus threshold, and the marine water began to fill the New Euxinian (Pontian) basin, which was gradually turned into the modern Black and Azov seas. In the Caspian Sea the cold and dry climate of the Younger Dryas led to a lowered level of the Khvalynian basin (Enotayevka regression). The subsequent sudden warming induced a transgressive rise of the sea level at the Late Khvalynian stage. The Khvalynian epoch in the Caspian Sea evolution ended with the Mangyshlak regression under conditions of a continental climate in the Boreal period of the Holocene.

\section{Acknowledgements}

The author used materials obtained in the surveys performed as a part of work on the projects of the RSF № 16-17-10103 (Ponto-Caspian region) and RFBR № 18-00-00470 (Eastern Caspian region). The author is thankful to all her colleagues who took part in the survey in the region.

\section{References}

Dynamics of landscape components and internal sea basins of the Northern Eurasia for the last 130000 years. 2002. In: Velichko A.A. (Ed). Moscow: GEOS. (in Russian)

Krijgsman W., Tesakov A., Yanina T. et al. 2019. Quaternary time scales for the Pontocaspian domain: interbasinal connectivity and faunal evolution. Earth-Science Reviews 188: 1-40.

North Greenland Ice Core Project members. 2004. Highresolution record of Northern Hemisphere climate extending into the last interglacial period. Nature 431: 147-151.

Rinterknecht V., Hang T., Gorlach A. et al. 2018. The Last Glacial Maximum extent of the Scandinavian Ice Sheet in the Valday Heights, western Russia: Evidence from cosmogenic surface exposure dating using ${ }^{10} \mathrm{Be}$. Quaternary Science Reviews 200: 106-113.

Svitoch A.A., Selivanov A.O., Yanina T.A. 1998. Paleogeographic events of the Pleistocene of the Ponto-Caspian and the Mediterranean seas (materials on reconstruction and correlation). Moscow: Publishing house of the Russian Academy of Agrarian Sciences. (in Russian)

Walker M., Johnsen S., Rasmussen S.O. et al. 2009. Formal definition and dating of the GSSP (Global Stratotype Section and Point) for the base of the Holocene using the Greenland NGRIP ice core, and selected auxiliary records. Journal of Quaternary Science 24(1): 3-17.

Yanina T.A. 2012. Neopleistocene of the Ponto-Caspian region: biostratigraphy, paleogeography, correlation. Moscow: Moscow University Publ. house. (in Russian) 